\title{
Painting with Words as Painters Paint: Pierre Loti's Concern with Perspective
}

\author{
Richard M. Berrong
}

\section{(2) OpenEdition}

1 Journals

\section{Electronic version}

URL: http://journals.openedition.org/studifrancesi/8804

DOI: 10.4000/studifrancesi.8804

ISSN: 2421-5856

\section{Publisher}

Rosenberg \& Sellier

\section{Printed version}

Date of publication: 1 October 2008

Number of pages: 396-404

ISSN: 0039-2944

\section{Electronic reference}

Richard M. Berrong, "Painting with Words as Painters Paint: Pierre Loti's Concern with Perspective", Studi Francesi [Online], 155 (LII | II) | 2008, Online since 30 November 2015, connection on 12 January 2021. URL: http://journals.openedition.org/studifrancesi/8804 ; DOI: https://doi.org/10.4000/ studifrancesi.8804

\section{(c) (i) $\odot$}

Studi Francesi è distribuita con Licenza Creative Commons Attribuzione - Non commerciale - Non opere derivate 4.0 Internazionale. 


\section{Painting with Words as Painters Paint: Pierre Loti's Concern with Perspective}

Even before he took to creating art with words, French novelist Pierre Loti (1850-1923) was an avid drawer ${ }^{1}$. So much so that, when he did write, he sometimes felt the need to supplement his verbal efforts with visual ones. In one of his autobiographically-based novels, Le Roman d'un enfant (1890), he recounts how, at the age of eight, he and his friend Lucette left absurd and incoherent letters in the street so that they could enjoy the reactions of those who stopped to read them. The narrator explains that these notes were written «avec dessins à l'appui intercalés dans le texte» $(\mathrm{XXVIII})^{2}$. At the age of fourteen, inspired by Rudolphe Töpffer, the inventor of the modern comic book ${ }^{3}$, Loti sketched out the text and some illustrations for a graphic story entitled Les Aventures de M Pygmalion Piquemouche et de Melle Clorinde sa poétique fiancée $e^{4}$. Even after he entered the navy three years later and began to travel the world, Loti continued to make many often very impressive drawings, some of which were published in the big Parisian illustrated papers, and at least a few interesting watercolors 5 . One commentator, Michel du Coglay, has gone so far as to proclaim that «à part Victor Hugo,... aucun homme de lettres n'a dessiné et peint comme Loti» ${ }^{6}$. While one might accuse du Coglay of Francocentrism and even forgetfulness - Fromentin, for example, was a significant painter - there is no denying that Loti was a strikingly accomplished pictorial artist $^{7}$.

In his late twenties, around the time he began writing novels, he evidently stopped painting. In 1910 the author told his personal secretary, Gaston Mauberger, «il y a trente ans que je n'ai pas pris un pinceau» ${ }^{8}$. Nonetheless, he continued to think

(1) Various of Loti's early drawings have been published in different books. See, for example, the edition of his novel Pêcheur d'Islande published by Michel de l'Ormeraie (Paris, 1985), which includes a drawing he did at the age of 12 (p. 195) and an evocative landscape that he sketched in his arithmetic notebook (p. 97).

(2) I follow the practice traditional in Loti scholarship of citing his novels by chapter number, since there are so many different editions of his works and the chapters are so short.

(3) On TöPfFER, cfr. Töpffer: L'Invention de la bande dessinée, ed. Thierry GROENSTEEN and Benoît PeEters, Paris, Hermann, 1994.

(4) A facimile edition was published in «Le Manuscrit autographe» 42-43 (1933), pp.120137. For a study of it, see G. SCAON, Les aventures de Monsieur Pygmalion Piquemouche, «Lettre d'information de l'Association pour la maison de Pierre Loti» 8 (Novembre 2003), pp. 3-11.

(5) On Loti's artwork, see, in addition to the sixteen volumes of his works that Michel de
l'Ormeraie brought out in the 1980s (cfr. ft. 1 above): C. W. BIRD, Pierre Loti, correspondant et dessinateur 1872-1889, Paris, P. André, 1948; C. Farrère, Cent dessins de Pierre Loti,Tours, Arrault, 1948; P. LOTI, Julien Viaud ou Pierre Loti: coureur des mers et coureur de rêves, Paris, Galerie Régine Lussan, 1994, vol. I; the serialization of Un Jeune officier pauvre in «La Petite Illustration» pp. 143146 (1923); Pierre Loti: Fantômes d'Orient, Paris, Musées, 2006; etc.

(6) M. Du Colgay, Le Vrai Loti, Tunis, La Kahena, 1941, p. 112.

(7) Loti's principal publisher, Calmann-Lévy, used thirty-three of the drawings Loti had made during his 1872 tour of duty in the South Pacific to illustrate a de luxe, large format edition of Le Mariage de Loti in 1898; they had already used sixteen of the water colors and drawings that Loti had done during his 1873 tour of duty in Africa to illustrate a more modest edition of Le Roman d'un spabi in 1893 .

(8) G. Mauberger, Dans l'intimité de Pierre Loti 
in terms of painting when creating worlds with words. In his literary works he often spoke of the scene he was describing as a "tableau", strove to convey the exact shades of its colors', etc. That much other writers have done, of course. Loti went further, however. He developed a literary aesthetic that found in painting a key to the creation of effective art across mediums.

One aspect of pictorial painting that particularly interested Loti was perspective. Near the end of Madame Chrysanthème (1887), his novelization of his 1885 sojourn in Japan, the unnamed Narrator, as he prepares to leave, decides to draw the room he has shared with the title character:

Donc, je cherche une feuille d'album et je commence tout de suite, assis par terre, appuyé sur mon pupitre à sauterelles en relief, - tandis que, derrière moi, les trois femmes [Chrysanthème, the Narrator's landlady Mme Prune, and her daughter Mlle Oyouki], bien près, bien près, suivent les mouvements de mon crayon avec une attention étonnée. Jamais elles n'avaient vu dessiner d'après nature, l'art japonais étant tout de convention, et ma manière les ravit. Peutêtre n'ai-je pas la sûreté ni la prestesse manuelle de M. Sucre [his landlord] lorsqu'il groupe ses charmantes cigognes, mais je possède quelques notions de perspective qui lui manquent;... alors ces trois Japonaises sont émerveillées de l'air réel de mon croquis (LI; first emphasis mine $)^{10}$.

Because it has perspective, the Narrator's drawing takes on the appearance of being real and thereby makes a great impression on his audience.

Three years after Madame Chrysanthème, Loti came out with two new booklength works, Au Maroc and Le Roman d'un enfant. The first is a depiction of his travels in Morocco in 1889 as part of a diplomatic mission, the second a depiction of the childhood and early adolescence of his Narrator that Loti modeled very much on his own ${ }^{11}$. In both the author explored how perspective and its effects might be transferred to literature, though in different ways.

Au Maroc reads like a series of paintings. In his Préface, the first introduction he wrote for one of his books, Loti explains that in this volume the reader will find only "pures descriptions", since that is what he wanted to "limit myself" to here. Indeed, the following text is just that, a series of descriptions of what Loti experienced as he traveled from Tangier to Fez and then back. There are almost no conversations, little background or ethnographic information, etc. Though he traveled to Fez as a part of the entourage of Jules Patenôtre, recently appointed minister to Tangier, and

(1903-1923), ed. Alain Quella-Villéger, Paris, Le Croît vif, 2003 , p. 81.

(9) In his efforts to convey the exact shade of a color, Loti followed the path set out by the Goncourt brothers in the novels they had written in the 1860s. Cfr. P. Sabatier, L'Esthétique des Goncourt, Geneva, Slatkine, 1970 , pp. 296-305.

(10) For the passage in his diary that Loti developed into this scene, see P. Loti, Cette éternelle nostalgie, ed. Bruno Vercier, Alain Quella-VILLÉGER, Guy Dugas, Paris, La Table ronde, 1997, p. 196.

It should probably be noted, to forestall reaction from those who know Japanese art, that the Narrator does not say that all Japanese painting lacked perspective, just M. Sucre's work. If his landlord's art lacks perspective, it is, perhaps, because the world in which he lived did so as well. Early in Madame Chrysanthème, on his way to meet the mariage broker who will eventually set him up with the novel's title character, the Narrator observes an "absence de lointains, de perspectives" (III) that, for him, distinguishes most of the Japan that he encounters.

(11) Assigning most of Loti's works to genres is futile. Au Maroc is a travelogue, but then so is Madame Chrysanthème, which is always regarded as a novel. Le Roman d'un enfant is clearly autobiographical, but very much a novel in the sense that Proust's Combray, which owes a great deal to it, is. Loti himself dismissed attempts to pigeon-hole his works into genres. In the Discours de réception he gave upon his election to the Académie française in 1892, he declared that «peu m'importe d'abord qu'un livre s'appelle roman ou s'intitule de tel autre nom qu'on voudra ... je fais un égal dédain des étiquettes et des règles, et je laisse disputer, sur la matière, les ergoteurs, impuissants à créer» (Discours de réception de Pierre Loti, Paris, CalmannLévy, 1892, p. 64). 
returned with $\mathrm{H}$. de Vialar, there is virtually no text devoted to personal interactions, either with the Europeans or with the Moroccans. As he is about to begin his exploration of Fez, for example, he notes that he is looking forward to being able to «circuler en liberté et voir d'un peu plus près les gens et les choses» (XXI; emphasis mine). As the repeated use of words like "tableau" and "encadrer" emphasizes, in this book Loti took advantage of the absence of a story line, characters, etc., to focus on painting with words what he describes as having seen. The reader often has the impression that, rather than reading a narrative, he is walking through an art gallery - albeit a modern one, since Loti is very careful to note tactile, aural, and sometimes olfactory as well as visual perceptions.

It should come as no surprise, given the closing scene in Madame Chrysanthème quoted above, that one of Loti's major concerns in developing these word paintings is perspective. With a frequency that cannot be the result of chance, the narrator, in describing one thing, repeatedly mentions something else in the same field of vision that is at a distance behind or in front of it. As they start out across the open terrain one morning on the way to Fez, «à quelque cinquante mètres en avant de nous, sur les tranquilles lointains verts sans cesse déroulés, - toujours se dessine cette même première avant-garde, qui nous guide et que nous suivons dans sa continuelle fuite» (VI; note Loti's choice of the verb "dessiner"). Another morning he exclaims, «Sur ces lointains si sombres comme nos tentes sont blanches!»(VIII). When they arrive before the walls of $\mathrm{Fez}$, he remarks how «les bannières rouges, les bannières vertes, les bannières jaunes s'agitent en l'air, sur le fond noirâtre des murailles» (XIX); etc. Sometimes Loti even marks out three different depths in the same sightline. As he returns toward Tangier, he describes how, «au-delà des lignes immenses de la plaine, les montagnes où nous entrerons demain sont dessinées comme d'un pinceau net et ferme, en couleurs franchement intenses, sur un vide très clair qui est le ciel» (XXXVI; note again the use of the verb "dessiner", and here the mention of "un pinceau").

Sometimes, rather than presenting two or three things at different distances in the same line of sight, Loti, so that we appreciate the depth in his tableau, leads our gaze from foreground to background. During a tour of Mekinez, for example, he notes that «de longues lignes de remparts crénélés s'en vont se perdre on ne sait où, parmi les halliers et les herbages, dans les lointains de la campagne déserte» (XXXIII).

As several of these examples illustrate, the author also used his foreground/ background presentations like a painter to set off one color by putting another, darker one behind it: the darkness in the distance makes the tents look particularly white, the blackish walls of Fez set off the red, green, and yellow banners flapping in the air before them, etc. Elsewhere, he describes the Sultan's infantry as «une haie entièrement rouge, d'un rouge vif qui tranche sur le gris monotone de la foule» (XIX). The monarch's musicians create an even more striking effect for the same reason:

encadrée dans les rangs de l'infanterie écarlate,... leurs couleurs sont... rangées au contraire comme à dessein pour s'aviver encore les uns par les autres: une robe pourpre à côté d'une robe bleu de roi; une robe orange entre une robe violet évêque et une robe verte. Sur le fond neutre des foules environnantes, et parmi les cavaliers voilés de mousseline, ils forment le groupe le plus bizarrement éclatant que j'aie jamais vu dans aucun pays du monde ${ }^{12}$ (ibidem, emphasis mine).

(12) In his very astute remarks on Au Maroc, Pierre Silvain points out that Loti may have known Delacroix's major painting of a similar scene, The Sultan of Morocco and his Entourage: «Songe-t-il à cet instant à Delacroix, caresse-t-il l'idée de rivaliser avec lui par les mots, de laisser à son tour un tableau qui ne pâlisse pas auprès de celui qu'il connaît à coup sûr, représentant le sultan Moulay-Abd-erRalnue entouré de sa garde devant la grande porte de Meknès?» (Le Jardin des retours, Paris, Verdier, 2002 , p. 72). Delacroix displayed the painting at the Salon of 1845; it now hangs at the Musée des Augustins in Toulouse. 
One of the most striking, most painterly such passages occurs on the journey to Fez. Having described the fields before him, Loti goes on to explain that

ce vert intense s'assombrit sous les nuées lourdes qui traînent; il tourne au gris sombre, puis, vers l'horizon, se mêle peu à peu, par plans dégradés, avec le noir des montagnes et du ciel... [The mules'] hautes selles à dossier, recouvertes de drap rouge, forment des taches de couleur éclatante sur ces fonds de teintes neutres, sur ces derniers plans d'un gris violacé d'encre. (VIII)

If the use of darker or duller colors in the background to set off brighter or more lively colors in the foreground had been a standard painterly technique for centuries, one might think of the English pre-Impressionist James McNeil Whistler when Loti juxtaposes not two dissimilar colors, but two only slightly different shades of the same largely muted tone: as he leaves Fez behind him, for example, he writes that «ça et là nous rencontrons de petits campements bédouins, aux teintes également brunes comme la terre, d'où sortent des fumées qui montent tout droit sur le gris foncé des lointains» (XXXII). One can easily imagine a canvas entitled Study in Browns and Greys ${ }^{13}$.

Au Maroc set the style for most of the eight other book-length travel narratives that Loti would publish over the next twenty-two years in alternation with his remaining novels ${ }^{14}$. Like it, most of them are short on dialogue, historical background, and character presentation, long on description. As in Au Maroc, Loti took advantage of the freedom from the need to develop plot or characters that the travelog genre afforded him to concentrate on developing textual equivalents of painterly techniques.

The first and most obvious reason for his desire to retain aspects of painting in his writing was that he appreciated the power of pictorial images to make viewers

(13) Loti's fascination with colors that move through shades into different colors, expressed in the example from $A u$ Maroc VIII above, also recalls the Impressionists. In a similar vein, the author elsewhere describes a night sky as «un vide immense, profond, limpide, qui est ce soir d'un bleu irisé, d'un bleu tournant, à l'horizon, au vert d'aiguemarine; il y a partout grand resplendissement, grande fête et grande magie de lumière» (XIV; note also the attention to light). Near the end of the journey, he paints a «ciel bleu qui commence à palir, à tourner au vert limpide» (XXXVII).

Loti's travelogues resemble Impressionist painting in another way as well. Monet in particular made much of his "plein air" - as opposed to studio work - approach to painting, arguing that it made for a more "real" depiction of the effects on which he focused. As we know now, however, after having started a canvas "en plein air", he sometimes completed it back in his studio. As Robert Rosenblum notes, «we now know, too, that far from executing all of his paintings entirely on the spot, [Monet] was quite capable of reworking them in his studio in order to create more satisfying aesthetic wholes, even at the expense of an impersonal snapshot veracity» (19th-Century Art, Upper Saddle River, Prentice Hall, 2005, p. 369). Loti in his travelogues has a tendency to exaggerate the immediacy of his work as well. Though, like his painterly contemporary's work, the word paintings in his travel narratives are based on observations he made during his journeys, something that he emphasized by putting dates on each section as if to suggest that we are actually reading the pages of his diary that he wrote while on those expeditions, in fact the travelogues are often substantially different from the corresponding diary entries, worked up months and sometimes even years later. As with Monet, Loti strove to make the reader-viewer believe she was seeing the artist's unmediated impression of/reaction to the world itself, even when that was not quite the case. His success at this can be seen in comments such as du Coglay's: «[Loti] ne transpose point: aucun prisme entre les êtres, la nature et lui» (p. 115); the sites described in Loti's books «se réfléchissent en l'eau transparente et fidèle du miroir que leur présente Loti» (p. 116); «Loti n'avait pas l'imagination; il ne pouvait peindre que ce qu'il avait regardé et vu; ses romans ne sont guère que des transpositions» (p. 117); etc.

(14) The other eight were: Le Désert, Jérusalem, and Galilée (1895), Les Derniers jours de Pékin (1902), L'Inde (sans les Anglais) (1903), Vers Ispahan (1904), La Mort de Philae (1909), Pèlerin d'Angkor (1912). 
imagine things with which they are not familiar. In Le Roman d'un enfant, the Narrator recalls how, during his childhood, he had been fascinated by the apocalyptic passages in the last book of the New Testament. He explains that «il y avait un livre du siècle dernier... dans lequel je voyais vivre ces choses: une Histoire de la Bible avec d'étranges images apocalyptiques où tous les lointains étaient noirs» (XXIV; note the effect of the dark background in making the foreground images that much more effective). While he admires «toute cette poésie de rêve et de terreur» in the Biblical text itself, the visual artist's images, here with a contrasting background, are what made him «vo[ir] vivre ces choses». Visual artistic images can stimulate more than just the visual part of the imagination, furthermore. In paging through an illustrated article in «Le Magasin pittoresque» devoted to Egypt, the young Pierre experienced «l'impression subite d'un chaud et morne soleil» (XXV; emphasis mine).

That he himself was so affected by visual images the Narrator explains, in part, by noting that he grew up in Rochefort, a city of whitewashed houses lacking almost any color: «au cours de ma vie, j'aurais donc été moins impressionné sans doute par la fantasmagorie changeante du monde, si je n'avais commencé l'étape dans un milieu presque incolore» (VIII). But, he goes on to add, there were other reasons as well. According to him, «les gens doués pour bien peindre (avec des couleurs ou avec des mots) sont probablement des espèces de demi-aveugles, qui vivent d'habitude dans une pénombre, dans un brouillard lunaire, le regard tourné en dedans, et qui alors, quand par hasard ils voient, sont impressionnés dix fois plus vivement que les autres hommes» (ibidem, note that he refers to writers as those who "paint" with words).

As Loti discovered early on, words can evoke effective visual images of settings as well as images. At one point the Narrator of Le Roman d'un enfant remarks that Castelnau, the name of a Medieval fortress in southwestern France, «est un nom ancien qui évoque pour moi des images de soleil, de lumière pure sur des hauteurs, de calme mélancholique dans des ruines, de recueillement devant des splendeurs mortes ensevelis depuis des siècles» (XLV). If here language evokes an image that the Narrator had already acquired visually, elsewhere, like those Bible story illustrations, it makes him see things with which he had had no visual contact. Having been forced to read (an apparently unillustrated edition of) Fénélon's even-then old-fashioned Télémaque, «je voyais assez nettement la Grèce, la blancheur de ses marbres sous son ciel pur» (XLIV; emphasis mine; note that he remembers what the novel made him see, not what if any effect it had on his idea of education, which is its ostensible intent). In the same sense, the Narrator notes that, having come across an old ship's log that described a South Seas voyage, «je vis en esprit tout autour de moi le morne et infini resplendissement bleu du Grand Océan austral» (LXXIV; emphasis mine).

Like a visual artist's creations, language can also evoke non-visual perceptions of surroundings: in Vergil's Ninth Eglogue «la sonorité de ce mot Bianoris... évoqua pour moi, tout à coup, avec une extraordinaire magie, l'impression des musiques que les insectes devaient faire autour des deux voyageurs, dans le silence d'un midi très chaud éclairé par un soleil plus jeune, dans la sereine tranquillité d'un mois de juin antique» (LXV). Note that it is not a description of the insects' sound or the heat or the sunlight that does this, but rather the sound of the word "Bianoris"15.

If Loti was intent on creating visual images in his readers' minds, however, it was primarily because he believed that memory stored experience using visual images and could therefore be most directly accessed by employing similar visual images. In

(15) This is very much in line with the Flaubert of Salammbô (1862), supposedly Loti's favorite novel, and the poets who appreciated the evocative potential of the uncommon, exotic word. 
Rêve, a piece he first published separately in 1888 while working on this issue, Loti explains, with regard to a recurring dream: «dans ma mémoire, je retrouvai d'abord la vision à son moment le plus intense, celui où tout à coup j'avais songé à elle [the woman in his dream], en reconnaissant son grand chapeau jeté sur cette chaise, et où, derrière moi, elle avait paru... Puis lentement, peu à peu, je me rappelai tout le reste» ${ }^{16}$. In Fantôme d'Orient, a novelization of his 1887 return to Istanbul that Loti published in 1892, he remarks, with regard to the elderly Kadidja, that «cette image d'Aziyadé [a woman he had known during his previous visit there]... persistait encore au fond de sa tête finissante» (IV; emphasis mine). In Vies de deux chattes, also written at this time, he says, of the sight of a white cat on a red cushion, «c'est l'image persistante, définitive, qui devait me rester d'elle, même après sa mort: une folle petite bête blanche, inattendue, s'ébattant sur fond rouge entre les robes de deuil de maman et de tante Claire» (IV; emphasis mine; note the role of the darker backgrounds). Because memory stores experience around visual images, similar visual images call up memories directly and easily: in Le Roman d'un enfant, the Narrator speaks of «ces associations incohérentes d'images qui m'étaient jadis si habituelles» (XLVIII). Because, as Proust would argue at length two decades later, our memories have attached to such images all the things that we felt when we experienced them - "tout le reste", as the Narrator refers to them in the passage from Rêve quoted above - visual images can evoke in us not only a visual recollection but also the feelings associated with it, thereby producing a sometimes very powerful response.

Loti had already suggested this in his 1886 masterpiece, Pêcheur d'Islande. When, after learning of his friend Sylvestre Moan's death in Vietnam, the Breton fisherman Yann Gaos goes up on the deck of the Marie and gazes at the cloudy North Atlantic sky, the text notes:

Mais, en un point de ce ciel, très bas, près des eaux [the clouds] faisaient une sorte de marbrure plus distincte, bien que très lointaine; un dessin mou, comme tracé par une main distraite;...

Lui, Yann, à mesure que ses prunelles mobiles s'habituaient à l'obscurité du dehors, il regardait de plus en plus cette marbrure unique du ciel; elle avait forme de quelqu'un qui s'affaisse, avec deux bras qui se tendent. Et à présent qu'il avait commencé à voir là cette apparence, il lui semblait que ce fût une vraie ombre humaine, agrandie, rendue gigantesque à force de venir de loin. Puis, dans son imagination ..., cette ombre triste... se mêlait peu à peu au souvenir de son frère mort, comme une dernière manifestation de lui... A contempler ce nuage, il sentait venir une tristesse profonde, angoissée, pleine d'inconnu et de mystère, qui lui glaçait l'âme;... Il revoyait la figure douce de Sylvestre, ses bons yeux d'enfant; à l'idée de l'embrasser, quelque chose comme un voile tombait tout à coup entre ses paupières, malgré lui,... les larmes commençaient à couler lourdes, rapides, sur ses joues; et puis des sanglots vinrent soulever sa poitrine profonde (III:9; emphasis added).

In describing the one section of the cloud-covered sky as «un dessin mou, comme tracé par une main distraite», the Narrator likens it to the work of a visual artist. Because of the similarity between that cloud form and a human form, it evokes in Yann's mind his memories of Sylvestre. And with those memories comes all the emotion Yann associated with Sylvestre, "tout le reste", producing a "tristesse profonde".

Therein, for Loti, lay the challenge in creating non-visual art. How can the writer, using only words, produce an image that will do as effective a job as visual art of

(16) First emphasis mine. Loti published Rêve independently in the August 1, 1888 issue of the «Fornightly Review», and then included it in Le
Livre de la pitié et de la mort (1891), a collection of pieces that also includes Vies de deux chattes, quoted below. 
linking to images stored in memory and calling up associated emotion? Speaking of his first novel, the novelist Narrator in Fantôme d'Orient remarks: «j'avais essayé de l'exprimer [the sadness that hangs over Constantinople], dans un de mes premiers livres, mais je n'avais pu y parvenir, et aujourd'hui, à chaque pierre, à chaque tombe que je reconnais sur ma route [visual images], me reviennent les impressions indicibles d'autrefois, avec ce tourment intérieur, qui aura été un des plus continuels de ma vie, de me trouver impuissant à peindre et à fixer avec des mots ce que je vois et ce que je sens, ce que je souffre... » (III; note that a writer is again described as "painting" with words). The visual images («chaque pierre», «chaque tombe», etc.) evoke memories and the feelings associated with them («les impressions indicibles d'autrefois»), but the Narrator finds it much more difficult to «fixer avec des mots» both the visual («ce que je vois») and the feelings attached to it («ce que je sens, ce que je souffre») $)^{17}$.

The author saw one possible way of dealing with this challenge, however. Once again it involved creating perspective, though this time in a more figurative way, and once again he described it in terms of (this time contemporary) painterly technique.

While they were fundamental in his conception of the workings of memory, Loti does not appear to have seen visual images as primary in the human mind. In a passage in Le Roman d'un enfant the Narrator recounts how, at the age of five or six, he made a simple drawing that he entitled Le Canard malbeureux on the blank verso of some printed page. As he looked at it,

les lettres, les lignes transparaissaient en taches grisâtres qui subitement produisirent à mes yeux l'impression des nuages du ciel; alors ce petit dessin, plus informe qu'un barbouillage d'écolier sur un mur de classe, se compléta étrangement de ces taches du fond, prit tout à coup pour moi une effrayante profondeur;... il s'agrandit comme une vision, se creusa au loin comme les surfaces pâles de la mer. J'étais épouvanté de mon oeuvre, y découvrant des choses que je n'y avais certainement pas mises et qui d'ailleurs devaient m'être à peine connues (IX; emphasis added).

It is, again, an artistic visual image, «ce petit dessin», that strikes the viewer, here the Narrator in his youth, so powerfully. But this time, the intentional part of the artist's work is "completed" by the addition of the clouds, which, with the part that the Narrator had sketched on his own, form the whole that has such an effect on him, in part because of its "profondeur". Though Freud - who would claim that he learned much about psychoanalysis from reading literature - had yet to formulate the terminology, Loti here proposes that the artist creates an effective artwork in part from his conscious intentions, in part from images that seep though from what

(17) Loti seems to have felt that music was also more direct than words at evoking stored visual images and the feelings associated with them. In Le Roman d'un enfant his Narrator recounts how, after having lost his dog Gaspard during a walk in the woods, a guest's desolate violin playing at a diner given by his parents that evening «fut pour moi comme une évocation de routes noires dans les bois, de grande nuit où l'on se sent abandonné et perdu; puis je vis très nettement Gaspard errer sous la pluie, à un carrefour sinistre, et, ne se reconnaissant plus, partir dans une direction inconnue pour ne revenir jamais... Alors les larmes me vinrent, et comme on ne s'en apercevait point, le violon continua de lancer dans le silence ses appels tristes, aux- quels répondaient, du fond des abîmes d'en dessous, des visions qui n'avaient plus de forme, plus de nom, plus de sens» (XI, emphasis mine).

This is a particularly good depiction of Loti's view of art, how it succeeds by calling up something in us that is already freighted with feeling. Of course, this passage very much recalls several in $A$ la recherche du temps perdu dealing with Vinteuil's music and its effect on first Swann and then the Narrator. Still, one should note that what makes the violin playing so powerful here is that it suggests visual images - «je vis très nettement... »- of what happened. It is these visual images that move the Narrator, again. 
Freud would name the subconscious, which consists of some sort of primary, unseen language (the unseen words on the recto of that page) ${ }^{18}$. While it is not spatial in the same sense as the perspective created in Madame Chrysanthème and Au Maroc, the "profondeur" that this "seepage" gives the artwork has an effect on the viewer that is every bit as powerful.

But does such "perspective" have to be involuntary? Does the writer just have to hope that his subconscious will make its way into his work as the ink happened to seep through the paper to create the clouds that made the Narrator's drawing so effective? Loti proposes a middle stance on this issue. He felt that, if he found the appropriate style, he could at least facilitate the entry of the subconscious into his texts. In Reve, the Narrator begins by announcing that «je voudrais connaittre une langue à part, dans laquelle pourraient s'écrire les visions de mes sommeils. Quand j'essaie avec les mots ordinaires, je n'arrive qu'à construire une sorte de récit gauche et lourde, à travers lequel ceux qui me lisent ne doivent assurément rien voir; moi seul, je puis distinguer encore, derrière l'à peu près de ces mots accumulés, l'insondable abîme» (emphasis mine). When he makes an effort to pin down his dreams in words («quand j'essaie»), he has no success. He only ends up with a lot of "mots accumulés" that only seem to block any sight of «l'insondable abîme» inside him. So he longs for a style that will allow his visions to be written, but also «to write themselves» ("s'écrire"), in his texts, a non-conscious act like the appearance of those clouds in the Narrator's drawing.

Coming up with such a style in writing would not be easy, however. In Pays sans nom, the recollection of a dream he supposedly had during his Moroccan trip that Loti published as part of Le Livre de la pitié et de la mort, this Narrator despaired that «les mots humains ne peuvent rendre les dessous de cette vision, le mystère et la tristesse de cette plaine ainsi réapparue, tout ce qui s'ébauchait en moi d'inquiétudes désolées» (emphasis mine). A few years before, in the central scene of Pêcheur d'Islande when Yann sees his dead friend Sylvestre in that cloud formation over the North Atlantic and finally confronts his grief, Loti had written: «Mais les mots, si vagues qu'ils soient, restent encore trop précis pour exprimer ces choses; il faudrait cette langue incertaine qui se parle quelquefois dans les rêves, et dont on ne retient au réveil que d'énigmatiques fragments n'ayant plus de sens» (III:9; cf. also the passage in Rêve quoted in the previous paragraph). Regular "human language" was, for Loti, too different from subconscious emotion, too "precise", to express it, to let in what is often only "ébauché".

Still, that sketchy childhood drawing, Le Canard malbeureux, had let the Narrator's subconscious in and worked as effective art as a result. This leads the Narrator of Le Roman d'un enfant to observe: «j'ai souvent remarqué du reste que des barbouillages rudimentaires tracés par des enfants, des tableaux aux couleurs fausses et froides, peuvent impressionner beaucoup plus que d'habiles ou géniales peintures, par cela précisément qu'ils sont incomplets et qu'on est conduit, en les regardant, à y ajouter mille choses de soi-même, mille choses sorties des tréfonds insondés et qu'aucun pinceau ne saurait saisir» (IX). If, as the Pêcheur d'Islande Narrator notes, regular language is "trop précis" to portray subconscious feelings, then perhaps the writer needs to develop a simpler language, like "cette langue incertaine qui se parle quelquefois dans les rêves", that, rather than trying to pin them down, leaves gaps that cause the reader to supply some things herself, as Yann did when looking at Pêcheur d'Islande's cloud-drawing ${ }^{19}$. One might also recall this Narrator's admiration

(18) Lacan has argued something similar in our own time.
(19) It is easy to see why, in certain of his texts, Loti worked toward creating a verbal equivalent 
for the way certain Japanese set off a few pieces in their houses, surrounding them with empty whiteness or space. Speaking of Mme Renoncule's house, for example, the Narrator remarks that «l'intérieur de ma belle-mère révèle à lui seul une personne raffinée: nudité complète; à peine deux ou trois paravents posés ça et là... ». To those Europeans of his era who were trying to decorate their homes in what they imagined to be Japanese style, «je leur conseille, à ces personnes, de venir regarder comment sont ici les maisons des gens de goût, - de venir visiter les solitudes blanches des palais de Yeddo... une simplicité apparente extrème dans l'ensemble... telle est la manière japonaise de comprendre le luxe intérieur» (XXXV). Van Gogh considered this passage revelatory. Rather than strive for absolute precision of language as his contemporaries the Realists and the Naturalists were attempting to do - "le mot juste", in Flaubert's celebrated if sometimes misused phrase - if a writer created such an intentionally imprecise style, she might find both that some of her "insondable abîme" had seeped into, had "written itself" into her text, and that the reader, faced with such imprecision, delved without thinking into his own "tréfonds insondés" to fill the apparent "gaps", thereby providing another source of depth/perspective and making the text appear even that much more "réel". Here "perspective", depth not in space as in Madame Chrysanthème and Au Maroc but in time, memory, and emotion, is again achieved by adopting a style derived from painting, this time one very similar to that of Loti's contemporaries, the Impressionists.

Though he chose a career as a writer rather than a visual artist, Loti evidently decided that he still had to give his writing some of the qualities of painting if it was to make the sort of deep and lasting impression on his readers that he sought and that he knew visual images, and in particular artistically-crafted visual images, could produce. Some of these qualities he worked to create most extensively in his travelogs; others, such as the sort of "perspective" a narrative acquires by making room for the author's - and the reader's - subconscious, he sought to achieve primarily in his novels. Loti's contemporaries often called him a painter with words ${ }^{20}$. It is, hopefully, now easier to see how his preoccupation with painting led him to develop his literary aesthetic in its terms. It is wonderfully appropriate that, upon his death in 1923, the Académie française chose to replace him with Albert Besnarel, the first painter to be elected to that body in over a hundred and fifty years.

RICHARD M. BERRONG

of Impressionist painting. On this, see: R. BERRONG, Modes of Literary Impressionism, «Genre», XXXIX, 2 (summer 2006), pp. 203-228.

One might note the Narrator's admiration, in Madame Chrysanthème, for Japanese vases decorated with «une simplicité si cherchée que, pour nos yeux, c'est comme une révélation d'inconnu, comme un renversement de toutes les notions acquises sur la forme» (XXXIV). This simplicity takes artis- tic effort: it is "cherchée".

(20) Cfr. for example L. Barthou, Pêcheur d'Islande de Pierre Loti, Paris, Mellottée, n.d., p. 298. In the 7 April, 1892, entry of his diary, Jules Renard recorded that Oscar Wilde had remarked to him over dinner: «Loti a imprimé ses aquarelles» (Journal, ed. L. Guichard et G. Sigaux, Paris, Gallimard, 1960, p. 123). 